\title{
Metabolic syndrome in HIV-infected individuals: underlying mechanisms and epidemiological aspects
}

\author{
Adelzon A Paula, Melissa CN Falcão and Antonio G Pacheco*
}

\begin{abstract}
The success of highly active antiretroviral therapy (HAART) has determined a dramatic decline in AIDS- and immunodeficiency-related causes of death in the HIV-infected population. As life-expectancy increases, such individuals have become gradually exposed not only to the effects of aging itself, but also to the influence of environmental risk factors, which are known to act in the general population. These features can lead to obesity, diabetes mellitus and ultimately cardiovascular diseases (CVD). Metabolic complications and abnormal fat distribution were frequently observed after a few years of antiretroviral therapy and, as the array of antiretroviral drugs became broader, long term metabolic alterations are becoming far more common worldwide. Nevertheless, the risk of not being on HAART is overwhelmingly greater than the metabolic adverse events in terms of morbidity and mortality events. HIV/ HAART-induced metabolic unbalances overlap in some extent the components of Metabolic Syndrome (MetS) and its high rates in the HIV population place infected individuals in an elevated CVD risk category. MetS can explain at least in part the emergence of CVD as the major morbidity and mortality conditions in the HIV population. In this review we convey information on the underlying aspects of MetS during HIV infection, highlighting some physiopathological and epidemiological features of this comorbidity along with the role played by HIV itself and the synergy action of some antiretroviral drugs. Considerations on MetS management in the HIV population are also depicted.
\end{abstract}

Keywords: HIV, Metabolic syndrome, Cardiovascular risk, AIDS, HAART

\section{Review}

\section{Introduction}

The introduction and widespread use of highly active antiretroviral therapy (HAART) in the mid 1990's, has led HIV-infected individuals to experience a dramatic decline in immunodeficiency-related events, including causes of death [1-3]. As a consequence, life-expectancy increased, which exposed them to the effects of aging itself, including the influence of the same environmental risk factors known to act in the general population and contributing to the occurrence of obesity, diabetes mellitus (DM), and cardiovascular diseases (CVD) $[4,5]$.

Metabolic syndrome (MetS) has been playing a major role as a marker for metabolic disorders [6]. According to the Third National Health and Nutrition Examination

\footnotetext{
* Correspondence: apacheco@fiocruz.br

Programa de Computação Científica, Fundação Oswaldo Cruz, Rio de Janeiro,
} Brasil

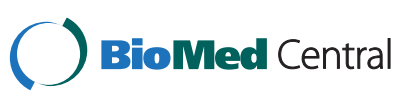

(C) 2013 de Paula et al.; licensee BioMed Central Ltd. This is an Open Access article distributed under the terms of the Creative Commons Attribution License (http://creativecommons.org/licenses/by/2.0), which permits unrestricted use, distribution, and reproduction in any medium, provided the original work is properly cited. The Creative Commons Public Domain Dedication waiver (http://creativecommons.org/publicdomain/zero/1.0/) applies to the data made available in this article, unless otherwise stated.
Survey, prevalence of MetS in the general US population has been estimated in $25 \%$ and this number has been growing continuously over time [7]. A recent British study on a cohort of middle-aged men reported the prevalence of MetS at 26\% [8]. The increasing prevalence of MetS relates to the growing tendencies verified for its underlying causes, such as unbalanced food intake, physical inactivity and obesity, which peaked in the developed world and have been suggested to be independent risk factors for the development of the syndrome [8].

MetS encompasses a cluster of risk factors leading to CVD as primary clinical outcome and contribute to higher risks of DM. Such factors include obesity (mainly central adiposity), defective glucose metabolism (DM, impaired glucose tolerance, or impaired fasting glycaemia), raised blood pressure, and elevated TG and low HDL-c levels. Notwithstanding the cardiovascular outcomes, individuals with MetS are thought to be more susceptible to a range 
of conditions including some cancers [9], polycystic ovary syndrome [10] and asthma [11].

Since its first comprehensive recognition in 1988, when Reaven described the relation between insulin resistance, plasma insulin levels, glucose intolerance and hypertension [12], MetS has been subject to a number of operational definitions. Despite the absence of a consensual definition to date, which dampers accurate prevalence estimates, the different working definitions for the syndrome converge to some extent. Four of the main MetS operational definitions and their differential and overlapping components can be seen in Table 1 .

\section{MetS in HIV infection}

Despite the unquestionable success of HAART, prevalence of DM, insulin resistance, blood pressure fat redistribution and mainly dyslipidemia have substantially increased after its global scaling up [17]. Though the actual numbers of MetS in HIV populations are still debatable, reported prevalences for MetS in the HIV population can be regarded as high, ranging from $11.2 \%$ up to $45.4 \%$ (Table 2). The high rates of MetS in the HIV-infected population place it in a CVD high-risk category, turning MetS into a major public health concern [18-20].

The natural course of HIV infection is associated with particular unbalances in lipid levels. The dynamics of HIV infection determine an initial decrease in HDL-c followed by a decrease in LDL-c levels. In more advanced stages, there is an increase in TG and in VLDL-c levels with a strong correlation between serum IFN- $\alpha$ levels and TG clearance time [30]. Notwithstanding, there is evidence for different MetS pathways among HIV individuals under HAART treatment, since a recent report indicated an unbalanced relationship between HDL-c and TG in the presence of high TG levels or another component of MetS [31], which claims for an appropriate MetS definition in HIV infection.

\section{Physiopathology of MetS in HIV-infected individuals}

Since the description of abnormal fat distribution following a few years on HAART with Protease Inhibitors (PI), chiefly ritonavir plus saquinavir combination [32], metabolic changes in HIV individuals have been widely studied. The main features included dyslipidemia, insulin resistance, and lipodystrophy. Many of these phenotypic and metabolic changes fit MetS criteria [18] and therefore, there is growing concern that metabolic complications associated to HIV and HAART may lead to increased risk for cardiovascular events. Such reasoning can explain, at least partially, the emergence of CVD as causes of morbidity and death in the HIV population.

HIV infection is associated with deregulated inflammatory response, through suppressing genes necessary to extinguish inflammation. In such context, HIV-infected monocytic cells have downregulated expression of the tyrosine kinase RON, a negative regulator of the inflammatory process and HIV transcription as well, via ubiquitinproteosome degradation [33]. This long term inflammatory environment along with higher white blood cells count act as a metabolic risk factor in the pathogenesis of HIV [34].

While obesity is a central component of MetS, adipose tissue is a dynamic source of several proinflammatory cytokines, chemokines, growth factors and complement proteins, which can alter endothelial cells integrity and contribute to the atherosclerosic process [35]. This constitutive low-grade inflammatory status is characterized by increased plasma levels of TNF- $\alpha$ and IL- 6 and other mediators of inflammation [36]. The interplay between HIVtriggered low-grade inflammatory injury, inbalances in lipid and glucose metabolism, and fat redistribution has already been described, with soluble urokinase plasminogen activator receptor (suPAR) emerging as a stronger predictor of dysmetabolism than TNF- $\alpha$ and IL-6 [37].

Insulin resistance is thought to determine excessive adipokine production yielding to endothelial dysfunction. As it progresses towards MetS and DM, the ongoing process of endothelial damage, along with inflammation, thrombosis and oxidation orchestrate at the vessel wall to produce atherosclerotic plaques [36]. Accordingly, caloric restriction-induced weight loss contributes to the regulation of a wide variety of inflammation-related molecules adipose tissue and upregulated the expression of molecules with anti-inflammatory properties [38].

\section{HIV-related risk factors}

Inflammation is thought to be a major determinant in the pathogenesis of both DM and atherosclerosis. However, the key inflammatory molecules involved in atheroma and DM in HIV individuals on HAART are poorly understood [39]. Epicardial and thoracic periaortic fat deposition have been associated to high levels of hsCRP, insulin resistance and subclinical atherosclerosis in virologically suppressed HIV-infected patients on HAART and both have been related to MetS $[40,41]$. In fact, epicardial fat storage and some lipodystrophy phenotypes and well established risk factors for atherosclerosis seem to be associated [42].

A case-control study performed among HIV-infected ART-naïve Africans showed a high prevalence of MetS and increased arterial stiffness, considered an early marker of atherosclerosis. In this report, prevalence of impaired fasting glucose and DM, levels of fasting TG and the atherogenic dyslipidemia ratio were higher in HIV-individuals than in controls. Elevated blood pressure prevalence was high but comparable in both groups [43].

Although to a lesser degree than HAART, HIV infection act as an independent risk factor for atherosclerosis development and cardiovascular damage, been responsible for 


\section{Table 1 Work definitions for MetS}

\begin{tabular}{|c|c|c|c|c|}
\hline Definition & EGIR (1999) [13] & NCEP/ATP III (2001) [14] & AHA-NHLBI (2005) [15] & IDF (2006) [16] \\
\hline Mandatory criteria & $\begin{array}{l}\text { Insulin resistance defined as the top } \\
25 \% \text { of the fasting insulin values } \\
\text { among nondiabetic individuals }\end{array}$ & None & None & Waist circumference ${ }^{\#}$ with ethnicity-specific values \\
\hline Aditional criteria & At least two of the following: & At least three of the following: & At least three of the following: & At least two of the following: \\
\hline Central obesity & $\begin{array}{l}\text { Waist circumference } \geq 94 \mathrm{~cm} \\
\quad(\text { male), } \geq 80 \mathrm{~cm} \text { (female) }\end{array}$ & $\begin{array}{l}\text { Waist circumference } \geq 102 \mathrm{~cm} \\
\text { or } 40 \text { inches (male), } \geq 88 \mathrm{~cm} \\
\quad \text { or } 35 \text { inches (female) }\end{array}$ & $\begin{array}{c}\text { Waist circumference } \geq 102 \mathrm{~cm} \\
\text { or } 40 \text { inches (male), } \geq 88 \mathrm{~cm} \text { or } \\
\quad 35 \text { inches (female) }\end{array}$ & See mandatory criteria \\
\hline Dyslipidemia & $\begin{array}{l}\mathrm{TG} \geq 2.0 \mathrm{mmol} / \mathrm{L} \text { and/or } \mathrm{HDL}-\mathrm{C}< \\
1.0 \mathrm{mmol} / \mathrm{L} \text { or treated for dyslipidemia }\end{array}$ & $\begin{array}{c}\mathrm{TG} \geq 1.7 \mathrm{mmol} / \mathrm{L}(150 \mathrm{mg} / \mathrm{dl}) \\
\mathrm{OR} \mathrm{HDL}-\mathrm{C}<40 \mathrm{mg} / \mathrm{dL} \\
\text { (male), }<50 \mathrm{mg} / \mathrm{dL} \text { (female) }\end{array}$ & $\begin{array}{c}\mathrm{TG} \geq 1.7 \mathrm{mmol} / \mathrm{L}(150 \mathrm{mg} / \mathrm{dl}) \\
\mathrm{OR} \mathrm{HDL}-\mathrm{C}<40 \mathrm{mg} / \mathrm{dL} \text { (male) } \\
\quad<50 \mathrm{mg} / \mathrm{dL} \text { (female) }\end{array}$ & $\begin{array}{c}\mathrm{TG}>150 \mathrm{mg} / \mathrm{dL}(1.7 \mathrm{mmol} / \mathrm{L}) \text {, or specific treatment for this lipid } \\
\text { abnormality } \mathrm{OR} \mathrm{HDL}-\mathrm{C}<40 \mathrm{mg} / \mathrm{dL}(1.03 \mathrm{mmol} / \mathrm{L}) \text { in males, } \\
<50 \mathrm{mg} / \mathrm{dL}(1.29 \mathrm{mmol} / \mathrm{L}) \text { in females, or specific } \\
\text { treatment for this lipid abnormality }\end{array}$ \\
\hline Blood pressure & $\begin{array}{l}\geq 140 / 90 \mathrm{mmHg} \text { or } \\
\text { antihypertensive medication }\end{array}$ & $\begin{array}{l}\geq 130 / 85 \mathrm{mmHg} \text { or } \\
\text { antihypertensive medication }\end{array}$ & $\geq 130 / 85 \mathrm{mmHg}$ & $\begin{array}{l}\text { Systolic } \mathrm{BP}>130 \mathrm{OR} \text { diastolic } \mathrm{BP}>85 \mathrm{mmHg} \text {, } \\
\text { or treatment of previously diagnosed hypertension }\end{array}$ \\
\hline Glucose metabolism & Fasting plasma glucose $\geq 6.1 \mathrm{mmol} / \mathrm{L}$ & $\begin{array}{l}\text { Fasting plasma glucose } \geq \\
6.1 \mathrm{mmol} / \mathrm{L}(110 \mathrm{mg} / \mathrm{dl})\end{array}$ & $\begin{array}{l}\text { Fasting plasma } \\
\text { Glucose } \geq 100 \mathrm{mg} / \mathrm{dL}\end{array}$ & $\begin{array}{l}\text { Raised fasting plasma glucose: }>100 \mathrm{mg} / \mathrm{dL} \\
(5.6 \mathrm{mmol} / \mathrm{L}) \text {, or previously diagnosed tDM }\end{array}$ \\
\hline
\end{tabular}

${ }^{\# I f ~ B M I ~ i s ~}>30 \mathrm{~kg} / \mathrm{m}^{2}$, central obesity can be assumed and waist circumferencedoes not need to be measured; BP: Blood Pressure. 
Table 2 MetS prevalences among different HIV populations

\begin{tabular}{|c|c|c|c|}
\hline MetS criteria & Prevalence (\%) & Remarks & Reference/year \\
\hline \multirow[t]{13}{*}{ NCEP-ATP III } & 45.4 & $\mathrm{n}=553$, Italy. & {$[21] / 2002$} \\
\hline & & On HAART & \\
\hline & 17 & $\mathrm{n}=710$, Spain & {$[22] / 2005$} \\
\hline & 22 & $\mathrm{n}=1243$ Italy & {$[23] / 2006$} \\
\hline & & SIMONE multicenter study & \\
\hline & 15.8 & $n=146$, Spain Madrid. & {$[24] / 2006$} \\
\hline & & On HAART, plus 159 HIV negative patients matched by BMI & \\
\hline & 18 & $n=788$ & {$[25] / 2007$} \\
\hline & & Lipodystrophy case definition cohort (international multicenter) & \\
\hline & 25.5 & $n=471$, USA. & {$[26] / 2007$} \\
\hline & & NHANES, matched for age, gender, ethnicity, tobacco use & \\
\hline & 20.8 & $n=1243$, Italy. & {$[25] / 2007$} \\
\hline & & SIMONE multicenter study & \\
\hline \multirow[t]{4}{*}{ EGIR } & 39.8 & $\mathrm{n}=201$, Italy. & {$[27] / 2002$} \\
\hline & & On HAART. & \\
\hline & 33.1 & $n=287$, Italy. & {$[28] / 2003$} \\
\hline & & On HAART & \\
\hline \multirow[t]{2}{*}{ NHLBI } & 24 & $n=77$, USA. & {$[20] / 2006$} \\
\hline & & NFHL Study & \\
\hline \multirow[t]{3}{*}{ IDF } & 14 & $n=788$ & {$[25] / 2007$} \\
\hline & & Lipodystrophy case definition cohort (international multicenter) & \\
\hline & 11.4 & $n=210$, Spain & {$[29] / 2007$} \\
\hline
\end{tabular}

the increased prevalence of MetS and arterial function impairment [44]. HIV-specific mechanisms include immune dysfunction and increased inflammatory response leading to increased thrombosis and changes in lipid levels and cholesterol metabolism, which are also responsible for MetS and cardiovascular risk in the general population. Tat, a key molecule in HIV replication and pathogenesis can affect both mesenchymal stem cells survival and differentiation by downregulating the expression of VEGF-induced endothelial markers and this might play an instrumental role in vessel damage and in the atherosclerotic lesions observed in HIV infection [45].

The pathogenesis of dyslipidemia in HIV-infected individuals has been associated with increased apolipoprotein levels, increased hepatic synthesis of VLDL-c, decreased clearance of TG [46] and also to the effects of viral infection itself, acute-phase proteins and increase in circulating cytokines such as IL- 6 and IFN- $\alpha$ [47]. In fact, lipid unbalances are common in art-naïve HIVinfected individuals even in the absence of major hostrelated risk factors for dyslipidemia, such as high blood pressure, DM and obesity [44].

HIV-1 infection itself is able to elicit adipose tissue alterations critical to lipodystrophy causation through adipose tissue gene expression alterations. Subcutaneous adipose tissue from infected individuals bears reduced mRNA levels of cytochrome c oxidase subunit II compared to non-infected individual. These concentrations decreased further in association with HAART [48].

\section{Antiretroviral-related risk factors}

HAART therapy has both positive and deleterious effects on cardiovascular risk. Cumulative evidence has pointed to the relation between different metabolic disorders and HAART use, including insulin resistance, hyperlipidaemia, and lipodystrophy [49], even though it remains controversial whether these effects can be directly ascribed to antiretroviral drugs [26]. Antiretroviral-driven suppression of HIV replication seem to act as double-edged sword since it can reduce and also increase HIV-related cardiovascular risk through its toxicity [50].

Despite effective treatment with HAART, some degree of chronic immune activation may persist. In the SMART trial, participants bearing $\leq 400$ copies/mL of HIV RNA also had elevated hsCRP and IL-6 levels in 38\% and 60\%, respectively, in comparison to normal individuals form cohorts for cardiovascular outcomes [51]. HIV-infected individuals have higher blood levels of major inflammation markers such as IL-6, hsCRP and p-selectin, considered independently associated with increased cardiovascular 
risk [52]. Interrupting ART use may further increase the risk of death by raising IL-6 and D-dimer levels [53].

HAART toxicity depends on the antiretroviral drug used and may include adverse lipoprotein changes, insulin resistance, inflammation, platelet dysfunction, and vascular injury. Studies performed in vitro have demonstrated that some HAART regimens, such as those including zidovudine, some NNRTI (e.g. efavirenz) and indinavir induce toxicity through induction of cardiomyocyte and endothelial cell apoptosis leading to endothelial dysfunction and vascular damage [54]. Thus, compared to untreated HIV infection, the net effect of starting antiretroviral therapy on cardiovascular disease risk is unknown as it may increase or decrease the overall risk [55]. Studies suggest that conventional risk factors will play major role in the development of CVD in HIV patients, as seen in the general population and such risk factors urge to be targeted by prevention strategies $[56,57]$.

The unbalances in glucose metabolism depend on the particular antiretroviral drug in use. Treatments with stavudine [58], zidovudine [59,60], lamivudine [59] or didanosine [58], as well as indinavir [61,62], or lopinavir/ritonavir [60], and efavirenz have [63,64] been implicated in insulin resistance, glucose metabolism changes, and DM. The pathways underlying such alterations are not always know but an in vitro essay with PIs and NRTIs showed altered adipocyte functions and decreased adiponectin, a positive regulator of insulin sensitivity, due to an increased expression and secretion of pro-inflammatory cytokines [65]. In another study, the PI indinavir has been implicated in inducing insulin resistance by acutely blocking transport of glucose by the insulin-sensitive glucose transporter GLUT4, a mechanism not found in non-HIV patients with DM [62].

Dyslipidemia in HIV population can result from both uncontrolled HIV disease and clinical restoration after HAART initiation. Individual, demographic and genetic traits besides the specific side effects of the antiretroviral combination contribute greatly to the type and degree of dyslipidemia seen in this population [66]. According to the D:A:D, a consortium assessing adverse events of antiHIV drugs, the risk associated to certain PI's (indinavir, lopinavir/ritonavir, abacavir) was consistently lower than the one calculated to the annual increment in risk associated to advanced age and current smoking habit [67]. The use of lopinavir/ritonavir [68], stavudine [63], efavirenz [69] and nelfinavir, zidovudine/lamivudine and didanosine/stavudine [70] have already been reported as causative of dyslipedemia by at least one of the following mechanisms (i) increased TG levels, (ii) increased LDL-c levels, and (iii) increased HDL-c levels.

Aside these specific cardiovascular risks, CVD have been reported as adverse effect with some ARV drugs, independently of metabolic disorders [71,72]. A meta-analysis indicated an increased risk of myocardial infarction in patients exposed to abacavir (RR 1.92, 95\% CI 1.51-2.42), and an increased risk associated with each additional year of exposure to indinavir (RR 1.11, 95\% CI 1.05-1.17) and lopinavir (RR 1.22, 95\% CI 1.01-1.47) [72]. A prospective observational study from the D:A:D consortium showed that combination antiretroviral therapy was independently associated with a relative increase of 1.26 times in the rate of myocardial infarction per year of exposure during the first four to six years of use [58]. Despite these minor metabolic unbalances described for many antiretroviral drugs, it is important to keep in mind that the morbidity and mortality risks for HIV patients not on HAART are much higher than the risks seen with any antiretroviral drug or combination of drugs.

\section{Targeting MetS risk factors in the HIV population}

As aforementioned, the success of HAART implementation allowed HIV individuals to live longer and as a consequence they can accumulate the same cardiovascular risks exposure described for the general population, such as high blood pressure, DM, dyslipidemia, and smoking habit, which is known to be a more prevalent risk in the HIV infected than in general population [73]. A French nationwide cohort of $\mathrm{HIV}^{+}$adults on HAART showed that nearly half the patients were overweight or obese at HAART initiation and $20 \%$ of the patients gained excessive weight within 2 years of HAART initiation [58]. Additionally, a retrospective cross-sectional study reported that, even though less common than among the general population, obesity and overweight were more prevalent in comparison to wasting in the HIV population [74].

In a recent cohort of HIV-infected patients receiving care in HIV clinics in US, $38.2 \%$ of patients were in either the moderately high-risk or high-risk categories, of whom $77.9 \%$ were current or past smokers, $74.2 \%$ had high blood pressure, $71.5 \%$ had elevated baseline LDL-c levels, 70.5\% had low HDL-c levels, and 35.8\% had MetS [75].

A recent study has suggested an exclusive map for estimating the correct risk of cardiovascular disease in these patients that should include, besides traditional risk factors, specific factors for HIV patients like viral factors, immune activation, chronic inflammation and side effects of antiretroviral therapy [75].

In managing hyperlipidemia, the decision to use lipidlowering therapy or to switch antiretroviral therapy regimens should be individualized. Unfortunately, at least one-fifth of HIV-infected outpatients with high cardiovascular risk who were eligible for pharmacologic treatment did not received recommended interventions and so treatment goals could not be achieved [75]. Effective management of dyslipidemia in HIV individuals is essential to reduce cardiovascular risk but presents multiple pitfalls due to interactions between HAART and lipid-lowering 
drugs [76]. A primary effort in treating dyslipidemia in HIV patients is selecting lipid-lowering agents capable to work effectively to restore lipid metabolism while maintaining proper interactions with HAART [77].

Beyond their canonical activity in inhibiting HMG-CoA reductase, statins might attenuate inflammation associate to the low-level viremia which can lead to a higher risk of age-associated non-AIDS morbidity and mortality. In fact, there is evidence showing that patients who maintained virologic suppression on effective HAART obtained additional survival benefit from the use of a statin [77].

As for the general population, cigarette smoking is thought to be the most important cardiovascular risk factor among HIV patients. More than half of the subjects evaluated in a cross-sectional analysis were current or past cigarette smokers, and smoking conferred a 2.35 $(95 \% \mathrm{CI}=1.92-2.87)$ risk for myocardial infarction [78]. Cessation of smoking was more likely to reduce cardiovascular risk than either the choice of the ART regimen or the use of lipid-lowering drugs [79]. When assessing carotid intima-media thickness as a surrogate marker of CVD in HIV cohort, only gender, age, BMI, hypertension and family history of CVD remained as significant factors associated with thickened carotid intima-media, suggesting that traditional CVD risk factors may play a major role in CVD among HIV population [57].

HIV individuals submitted to short-term exercise training can undergo reductions in the waist-to-hip ratio and in the amount of visceral fat, and reductions in the levels of cholesterol, triglyceride, and LDL-c and such changes may improve some of the adverse metabolic effects associated to HAART [80]. The assessing of aerobic training in improving abdominal fat accumulation and metabolic disorders in HIV infection revealed that it reduced visceral fat, lipid disorders, basal blood lactate and coronary heart disease and may be particularly important for patients with marked dyslipidemia [81].

\section{Conclusions}

The current HAART-modified natural history of HIV infection has practically turned the disease into a manageable chronic condition. As such, special attention should be paid to both imperfect control of HIV replication and long-term adverse events linked to drugs used in the therapeutic scheme. Even though the benefits of HAART use are overwhelmingly greater than possible MetS and CVD risks, close management of those patients is called for, especially due to the fact that general population risk factors now overlap with specific ones in this population, even though the former are usually more prominent than the latter.

Thus, MetS in HIV populations ought to be closely monitored and controlled by programmatic and comprehensive public measures. These findings call for an integrated management strategy, including smoking cessation policies, diet modification, and regular physical activity planning. Finally, comprehensive educational measures are needed and further research is instrumental to assess the barriers to implement preconized interventions and to achieving recommended treatment goals that are singular to the HIV-population.

\begin{abstract}
Abbreviations
AHA: American heart association; BMI: Body mass index; CVD: Cardiovascular disease; D:A:D: Data collection on adverse events of anti-HIV drugs; EGIR: European group for study of insulin resistance; HDL-c: High density lipoprotein cholesterol; hsCRP: High sensitivity C-reactive protein;

IFN-a: Interferon- a; IL-6: Interleukin-6; IDF: International diabetes federation; LDL-c: Low density lipoprotein cholesterol; MetS: Metabolic syndrome; NCEP/ ATP III: National cholesterol education program/adult treatment panel III; NCEP/ATP III: National heart, lung and blood institute; NNRTI:

Non-nucleoside reverse transcriptase inhibitors; NRTI: Nucleoside reverse transcriptase inhibitors; PI: Protease inhibitors; SMART: Strategies for management of anti-retroviral therapy; TG: Triglycerides; TNF-a: Tumor necrosis factor; DM: Type 2 diabetes mellitus; VEGF: Vascular endothelial growth factor; VLDL-c: Very low density lipoprotein cholesterol.
\end{abstract}

Competing interests

The authors declare that they have no competing interest.

\section{Authors' contributions}

AAP: drafted the manuscript; MCNF: drafted the manuscript; AGP: conceived and drafted the manuscript. All authors read and approved the final manuscript.

\section{Acknowledgements}

This study has been partially funded by Fundação de Amparo à Pesquisa do Estado do Rio de Janeiro (FAPERJ), Conselho Nacional de Desenvolvimento Científico e Tecnológico (CNPq) and Coordenação de Aperfeiçoamento de Pessoal de Ensino Superior (Capes).

Received: 29 October 2013 Accepted: 26 November 2013 Published: 13 December 2013

\section{References}

1. Grinsztejn B, Luz PM, Pacheco AG, Santos DV, Velasque L, Moreira RI, Guimaraes MR, Nunes EP, Lemos AS, Ribeiro SR, et al: Changing mortality profile among HIV-infected patients in Rio de Janeiro, Brazil: Shifting from AIDS to non-AIDS related conditions in the HAART era. PLOS One 2013, 8:e59768.

2. Krentz HB, Kliewer G, Gill MJ: Changing mortality rates and causes of death for HIV-infected individuals living in Southern Alberta, Canada from 1984 to 2003. HIV Med 2005, 6:99-106

3. Pacheco AG, Tuboi SH, May SB, Moreira LF, Ramadas L, Nunes EP, Mercon M, Faulhaber JC, Harrison LH, Schechter M: Temporal changes in causes of death among HIV-infected patients in the HAART era in Rio de Janeiro, Brazil. J Acquir Immune Defic Syndr 2009, 51:624-630.

4. Pacheco AG, Tuboi SH, Faulhaber JC, Harrison LH, Schechter M: Increase in non-AIDS related conditions as causes of death among HIV-infected individuals in the HAART era in Brazil. PLoS One 2008, 3:e1531.

5. Tate T, Willig AL, Willig JH, Raper JL, Moneyham L, Kempf MC, Saag MS, Mugavero MJ: HIV infection and obesity: Where did all the wasting go? Antivir Ther 2012, 17:1281-1289.

6. Rosolova H, Nussbaumerova B: Cardio-metabolic risk prediction should be superior to cardiovascular risk assessment in primary prevention of cardiovascular diseases. EPMA J 2011, 2:15-26.

7. Mozumdar A, Liguori G: Persistent increase of prevalence of metabolic syndrome among U.S. adults: NHANES III to NHANES 1999-2006. Diabetes Care 2011, 34:216-219.

8. Wannamethee SG: The metabolic syndrome and cardiovascular risk in the British Regional Heart Study. Int J Obes 2008, 32(Suppl 2):S25-S29.

9. Westley RL, May FE: A twenty-first century cancer epidemic caused by obesity: the involvement of insulin, diabetes, and insulin-like growth factors. Int J Endocrinol 2013, 2013:632461. 
10. Teede H, Deeks A, Moran L: Polycystic ovary syndrome: a complex condition with psychological, reproductive and metabolic manifestations that impacts on health across the lifespan. BMC Med 2010, 8:41.

11. Brumpton BM, Camargo CA Jr, Romundstad PR, Langhammer A, Chen $Y$, Mai XM: Metabolic syndrome and incidence of asthma in adults: The HUNT study. Eur Respir J 2013.

12. Reaven GM: Banting lecture 1988. Role of insulin resistance in human disease. Diabetes 1988, 37:1595-1607.

13. Balkau B, Charles MA: Comment on the provisional report from the WHO consultation. European Group for the Study of Insulin Resistance (EGIR). Diabet Med 1999, 16:442-443.

14. Expert Panel on Detection E, Treatment of High Blood Cholesterol in A: Executive summary of the third report of the National Cholestero Education Program (NCEP) expert panel on detection, evaluation, and treatment of high blood cholesterol in adults (adult treatment panel III). JAMA 2001, 285:2486-2497.

15. Grundy SM, Cleeman JI, Daniels SR, Donato KA, Eckel RH, Franklin BA Gordon DJ, Krauss RM, Savage PJ, Smith SC Jr, et al: Diagnosis and management of the metabolic syndrome: an American Heart Association/National Heart, Lung, and Blood Institute scientific statement: Executive Summary. Crit Pathw Cardiol 2005, 4:198-203.

16. Alberti KG, Zimmet P, Shaw J: Group IDFETFC: The metabolic syndrome-a new worldwide definition. Lancet 2005, 366:1059-1062.

17. Barbaro G: Metabolic and cardiovascular complications of highly active antiretroviral therapy for HIV infection. Curr HIV Res 2006, 4:79-85.

18. Biron A, Bobin-Dubigeon C, Volteau C, Piroth L, Perre P, Leport C, Prazuck T, Jovelin T, Billard M, Sebille V, et al: Metabolic syndrome in French HIV-infected patients: Prevalence and predictive factors after 3 years of antiretroviral therapy. AIDS Res Hum Retroviruses 2012, 28:1672-1678.

19. Feleke $Y$, Fekade D, Mezegebu Y: Prevalence of highly active antiretroviral therapy associated metabolic abnormalities and lipodystrophy in HIV infected patients. Ethiop Med J 2012, 50:221-230.

20. Jacobson DL, Tang AM, Spiegelman D, Thomas AM, Skinner S, Gorbach SL, Wanke C: Incidence of metabolic syndrome in a cohort of HIV-infected adults and prevalence relative to the US population (National Health and Nutrition Examination Survey). J Acquir Immune Defic Syndr 2006, 43:458-466.

21. Gazzaruso C, Sacchi P, Garzaniti A, Fratino P, Bruno R, Filice G: Prevalence of metabolic syndrome among HIV patients. Diabetes Care 2002, 25:1253-1254.

22. Jerico C, Knobel H, Montero M, Ordonez-Llanos J, Guelar A, Gimeno JL, Saballs P, Lopez-Colomes JL, Pedro-Botet J: Metabolic syndrome among HIV-infected patients: prevalence, characteristics, and related factors. Diabetes Care 2005, 28:132-137.

23. Bonfanti P, Ricci E, De Socio G, Zeme D, Carradori S, Penco G, Parruti G, Grosso C, Madeddu G, Vichi F, et al: Metabolic syndrome: A real threat for HIV-positive patients?: Results from the SIMONE study. J Acquir Immune Defic Syndr 2006, 42:128-131

24. Estrada V, Martinez-Larrad MT, Gonzalez-Sanchez JL, De Villar NG, Zabena C, Fernandez C, Serrano-Rios M: Lipodystrophy and metabolic syndrome in HIV-infected patients treated with antiretroviral therapy. Metabolism 2006, 55:940-945.

25. Samaras K, Wand H, Law M, Emery S, Cooper D, Carr A: Prevalence of metabolic syndrome in HIV-infected patients receiving highly active antiretroviral therapy using International Diabetes Foundation and Adult Treatment Panel III criteria: Associations with insulin resistance, disturbed body fat compartmentalization, elevated C-reactive protein, and [corrected] hypoadiponectinemia. Diabetes Care 2007, 30:113-119.

26. Mondy K, Overton ET, Grubb J, Tong S, Seyfried W, Powderly W, Yarasheski K. Metabolic syndrome in HIV-infected patients from an urban, midwestern US outpatient population. Clin Infect Dis 2007, 44:726-734.

27. Bruno R, Gazzaruso C, Sacchi P, Zocchetti C, Giordanetti S, Garzaniti A Ciappina V, Maffezzini E, Maserati R, Filice G: High prevalence of metabolic syndrome among HIV-infected patients: Link with the cardiovascular risk. J Acquir Immune Defic Syndr 2002, 31:363-365.

28. Gazzaruso C, Bruno R, Garzaniti A, Giordanetti S, Fratino P, Sacchi P, Filice G. Hypertension among HIV patients: Prevalence and relationships to insulin resistance and metabolic syndrome. J Hypertens 2003, 21:1377-1382

29. Bernal E, Masia M, Padilla S, Martin-Hidalgo A, Gutierrez F: Prevalence and characteristics of metabolic syndrome among HIV-infected patients from a Mediterranean cohort. Med Clin 2007, 128:172-175. quiz 171 p following 200.

30. Grunfeld C, Pang M, Doerrler W, Shigenaga JK, Jensen P, Feingold KR: Lipids, lipoproteins, triglyceride clearance, and cytokines in human immunodeficiency virus infection and the acquired immunodeficiency syndrome. J Clin Endocrinol Metab 1992, 74:1045-1052.

31. Vu CN, Ruiz-Esponda R, Yang E, Chang E, Gillard B, Pownall HJ, Hoogeveen RC, Coraza I, Balasubramanyam A: Altered relationship of plasma triglycerides to HDL cholesterol in patients with HIV/HAART-associated dyslipidemia: Further evidence for a unique form of metabolic syndrome in HIV patients. Metabolism 2013, 62:1014-1020.

32. Carr A, Samaras K, Burton S, Law M, Freund J, Chisholm DJ, Cooper DA: A syndrome of peripheral lipodystrophy, hyperlipidaemia and insulin resistance in patients receiving HIV protease inhibitors. AIDS 1998, 12:F51-58.

33. Kalantari P, Harandi OF, Hankey PA, Henderson AJ: HIV-1 Tat mediates degradation of RON receptor tyrosine kinase, a regulator of inflammation. J Immunol 2008, 181:1548-1555.

34. Farhangi MA, Keshavarz SA, Eshraghian M, Ostadrahimi A, Saboor-Yaraghi AA: White blood cell count in women: Relation to inflammatory biomarkers, haematological profiles, visceral adiposity, and other cardiovascular risk factors. J Health Popul Nutr 2013, 31:58-64.

35. Lyon CJ, Law RE, Hsueh WA: Minireview: adiposity, inflammation, and atherogenesis. Endocrinology 2003, 144:2195-2200

36. Bastard JP, Maachi M, Lagathu C, Kim MJ, Caron M, Vidal H, Capeau J, Feve B: Recent advances in the relationship between obesity, inflammation, and insulin resistance. Eur Cytokine Netw 2006, 17:4-12.

37. Andersen O, Eugen-Olsen J, Kofoed K, Iversen J, Haugaard SB: Soluble urokinase plasminogen activator receptor is a marker of dysmetabolism in HIV-infected patients receiving highly active antiretroviral therapy. J Med Virol 2008, 80:209-216

38. Clement K, Viguerie N, Poitou C, Carette C, Pelloux V, Curat CA, Sicard A, Rome $S$, Benis A, Zucker JD, et al: Weight loss regulates inflammationrelated genes in white adipose tissue of obese subjects. FASEB J 2004 18:1657-1669

39. De Lorenzo F, Collot-Teixeira S, Boffito M, Feher M, Gazzard B, McGregor JL: Metabolic-inflammatory changes, and accelerated atherosclerosis in HIV patients: Rationale for preventative measures. Curr Med Chem 2008, 15:2991-2999.

40. Longenecker $C T$, Jiang $Y$, Yun $C H$, Debanne S, Funderburg NT, Lederman MM, Storer N, Labbato DE, Bezerra HG, McComsey GA: Perivascular fat, inflammation, and cardiovascular risk in HIV-infected patients on antiretroviral therapy. Int J Cardiol 2013, 13:414-425.

41. Yerramasu A, Dey D, Venuraju S, Anand DV, Atwal S, Corder R, Berman DS, Lahiri A: Increased volume of epicardial fat is an independent risk factor for accelerated progression of sub-clinical coronary atherosclerosis. Atherosclerosis 2012, 220:223-230.

42. Sacks HS, Fain JN: Human epicardial adipose tissue: A review. Am Heart $J$ 2007, 153:907-917.

43. Ngatchou W, Lemogoum D, Ndobo P, Yagnigni E, Tiogou E, Nga E, Kouanfack C, Van de Borne P, Hermans MP: Increased burden and severity of metabolic syndrome and arterial stiffness in treatment-naive HIV + patients from Cameroon. Vasc Health Risk Manag 2013, 9:509-516.

44. Maloberti A, Giannattasio C, Dozio D, Betelli M, Villa P, Nava S, Cesana F, Facchetti R, Giupponi L, Castagna F, et al: Metabolic Syndrome in Human Immunodeficiency Virus-Positive Subjects: Prevalence, Phenotype, and Related Alterations in Arterial Structure and Function. Metab Syndr Relat Disord 2013, 3:214-219.

45. Gibellini D, Miserocchi A, Tazzari PL, Ricci F, Clo A, Morini S, Ponti C, Pasquinelli G, Bon I, Pagliaro P, et al: Analysis of the effects of HIV-1 Tat on the survival and differentiation of vessel wall-derived mesenchymal stem cells. J Cell Biochem 2012, 113:1132-1141.

46. Daniyam C, Iroezindu M: Lipid Profile of Anti-Retroviral Treatment-Naive HIV-Infected Patients in Jos, Nigeria. Ann Med Health Sci Res 2013, 3:26-30.

47. Crowe SM, Westhorpe CL, Mukhamedova N, Jaworowski A, Sviridov D, Bukrinsky M: The macrophage: The intersection between HIV infection and atherosclerosis. J Leukoc Biol 2010, 87:589-598.

48. Giralt M, Domingo P, Guallar JP, De la Concepcion ML R, Alegre M, Domingo JC, Villarroya F: HIV-1 infection alters gene expression in adipose tissue, which contributes to HIV- 1/HAART-associated lipodystrophy. Antivir Ther 2006, 11:729-740.

49. Wand H, Calmy A, Carey DL, Samaras K, Carr A, Law MG, Cooper DA, Emery S, Committee ITIC: Metabolic syndrome, cardiovascular disease and type 2 diabetes mellitus after initiation of antiretroviral therapy in HIV infection. AIDS 2007, 21:2445-2453. 
50. Palella FJ Jr, Baker RK, Moorman AC, Chmiel JS, Wood KC, Brooks JT, Holmberg SD: Investigators HIVOS: Mortality in the highly active antiretroviral therapy era: Changing causes of death and disease in the HIV outpatient study. J Acquir Immune Defic Syndr 2006, 43:27-34.

51. Neuhaus J, Jacobs DR Jr, Baker JV, Calmy A, Duprez D, La Rosa A, Kuller LH, Pett SL, Ristola M, Ross MJ, et al: Markers of inflammation, coagulation, and renal function are elevated in adults with HIV infection. J Infect Dis 2010, 201:1788-1795.

52. De Luca A, De Gaetano Donati K, Colafigli M, Cozzi-Lepri A, De Curtis A, Gori A, Sighinolfi L, Giacometti A, Capobianchi MR ADA, et al: The association of high-sensitivity c-reactive protein and other biomarkers with cardiovascular disease in patients treated for HIV: a nested case-control study. BMC Infect Dis 2013, 13:414.

53. Kuller LH, Tracy R, Belloso W, De Wit S, Drummond F, Lane HC, Ledergerber B, Lundgren J, Neuhaus J, Nixon D, et al: Inflammatory and coagulation biomarkers and mortality in patients with HIV infection. PLOS Med 2008, 5:e203.

54. Fiala M, Murphy T, MacDougall J, Yang W, Luque A, Iruela-Arispe L, Cashman J, Buga G, Byrns RE, Barbaro G, Arthos J: HAART drugs induce mitochondrial damage and intercellular gaps and gp120 causes apoptosis. Cardiovasc Toxicol 2004, 4:327-337.

55. Baker JV, Lundgren JD: Cardiovascular implications from untreated human immunodeficiency virus infection. Eur Heart J 2011, 32:945-951.

56. Sabin CA, Worm SW: Conventional cardiovascular risk factors in HIV infection: How conventional are they? Curr Opin HIV AIDS 2008, 3:214-219.

57. Pacheco AGFGB, Fonseca MDJ, Moreira RI, Veloso VG, Friedman RK, Cardoso SW, Falcão M, Mil JG, Bensenor I, Lotufo P, Chor D: Carotid intima-media thickness (CIMT) in HIV-infected patients in Rio de Janeiro, Brazil: Overall and gender analysis, 7th IAS Conference on HIV Pathogenesis, Treatment and Prevention. Kuala Lumpur; Birmingham, AL, USA; 2013.

58. Capeau J, Bouteloup V, Katlama C, Bastard JP, Guiyedi V, Salmon-Ceron D, Protopopescu C, Leport C, Raffi F, Chene G: Group ACA-CCS: Ten-year diabetes incidence in $1046 \mathrm{HIV}$-infected patients started on a combination antiretroviral treatment. AIDS 2012, 26:303-314.

59. Blumer RM, Van Vonderen MG, Sutinen J, Hassink E, Ackermans M, Van Agtmael MA, Yki-Jarvinen H, Danner SA, Reiss P, Sauerwein HP: Zidovudine/ lamivudine contributes to insulin resistance within 3 months of starting combination antiretroviral therapy. AIDS 2008, 22:227-236.

60. Van Vonderen MG, Blumer RM, Hassink EA, Sutinen J, Ackermans MT, Van Agtmael MA, Yki-Jarvinen H, Danner SA, Serlie MJ, Sauerwein HP, Reiss P: Insulin sensitivity in multiple pathways is differently affected during zidovudine/lamivudine-containing compared with NRTI-sparing combination antiretroviral therapy. J Acquir Immune Defic Syndr 2010, 53:186-193.

61. Palacios R, Merchante N, Macias J, Gonzalez M, Castillo J, Ruiz J, Marquez M, Gomez-Mateos J, Pineda JA, Santos J: Incidence of and risk factors for insulin resistance in treatment-naive HIV-infected patients 48 weeks after starting highly active antiretroviral therapy. Antivir Ther 2006, 11:529-535.

62. Murata H, Hruz PW, Mueckler M: The mechanism of insulin resistance caused by HIV protease inhibitor therapy. J Bio/ Chem 2000, 275:20251-20254.

63. Dave JA, Lambert EV, Badri M, West S, Maartens G, Levitt NS: Effect of nonnucleoside reverse transcriptase inhibitor-based antiretroviral therapy on dysglycemia and insulin sensitivity in South African HIV-infected patients. J Acquir Immune Defic Syndr 2011, 57:284-289.

64. Rosenkranz SL, Yarasheski KE, Para MF, Reichman RC, Morse GD: Antiretroviral drug levels and interactions affect lipid, lipoprotein, and glucose metabolism in HIV-1 seronegative subjects: A pharmacokineticpharmacodynamic analysis. Metab Syndr Relat Disord 2007, 5:163-173.

65. Lagathu C, Kim M, Maachi M, Vigouroux C, Cervera P, Capeau J, Caron M, Bastard JP: HIV antiretroviral treatment alters adipokine expression and insulin sensitivity of adipose tissue in vitro and in vivo. Biochimie 2005, 87:65-71.

66. Moog AM, Becker W: Management of dyslipidemia in HIV-infected patients. MMW Fortschr Med 2012, 154(Suppl 1):34-36.

67. Friis-Moller $N$, Thiebaut R, Reiss $P$, Weber R, Monforte AD, De Wit S, El-Sadr W, Fontas E, Worm S, Kirk O, et al: Predicting the risk of cardiovascular disease in HIV-infected patients: The data collection on adverse effects of anti-HIV drugs study. Eur J Cardiovasc Prev Rehabil 2010, 17:491-501.

68. Pinto Neto LF, Das Neves MB, Ribeiro-Rodrigues R, Page K, Miranda AE: Dyslipidemia and fasting glucose impairment among HIV patients three years after the first antiretroviral regimen in a Brazilian AIDS outpatient clinic. Braz J Infect Dis 2013, 17:438-443.
69. Gotti D, Cesana BM, Albini L, Calabresi A, Izzo I, Foca E, Motta D, Bellagamba R, Fezza R, Narciso P, et al: Increase in standard cholesterol and large HDL particle subclasses in antiretroviral-naive patients prescribed efavirenz compared to atazanavir/ritonavir. HIV Clin Trials 2012, 13:245-255.

70. Dube MP, Parker RA, Tebas P, Grinspoon SK, Zackin RA, Robbins GK, Roubenoff R, Shafer RW, Wininger DA, Meyer WA 3rd, et al: Glucose metabolism, lipid, and body fat changes in antiretroviral-naive subjects randomized to nelfinavir or efavirenz plus dual nucleosides. AIDS 2005, 19:1807-1818

71. Souza SJ, Luzia LA, Santos SS, Rondo PH: Lipid profile of HIV-infected patients in relation to antiretroviral therapy: A review. Rev Assoc Med Bras 2013, 59:186-198.

72. Bavinger C, Bendavid E, Niehaus K, Olshen RA, Olkin I, Sundaram V, Wein N, Holodniy M, Hou N, Owens DK, Desai M: Risk of cardiovascular disease from antiretroviral therapy for HIV: A systematic review. PloS One 2013, 8:e59551.

73. Vidrine DJ: Cigarette smoking and HIV/AIDS: Health implications, smoker characteristics and cessation strategies. AIDS Educ Prev 2009, 21:3-13.

74. Amorosa V, Synnestvedt M, Gross R, Friedman H, MacGregor RR, Gudonis D, Frank I, Tebas P: A tale of 2 epidemics: The intersection between obesity and HIV infection in Philadelphia. J Acquir Immune Defic Syndr 2005, 39:557-561.

75. Lichtenstein KA, Armon C, Buchacz K, Chmiel JS, Buckner K, Tedaldi E, Wood K, Holmberg SD, Brooks JT, Investigators H: Provider compliance with guidelines for management of cardiovascular risk in HIV-infected patients. Prev Chronic Dis 2013, 10:E10.

76. Malvestutto CD, Aberg JA: Management of dyslipidemia in HIV-infected patients. Clin Lipidol 2011, 6:447-462.

77. Moore RD, Bartlett JG, Gallant JE: Association between use of HMG CoA reductase inhibitors and mortality in HIV-infected patients. PLOS One 2011, 6:e21843.

78. Friis-Moller N, Weber R, Reiss P, Thiebaut R, Kirk O, D'Arminio Monforte A, Pradier C, Morfeldt L, Mateu S, Law M, et al: Cardiovascular disease risk factors in HIV patients-association with antiretroviral therapy. Results from the DAD study. AIDS 2003, 17:1179-1193.

79. Grinspoon S, Carr A: Cardiovascular risk and body-fat abnormalities in HIV-infected adults. N Engl J Med 2005, 352:48-62.

80. Jones SP, Doran DA, Leatt PB, Maher B, Pirmohamed M: Short-term exercise training improves body composition and hyperlipidaemia in HIV-positive individuals with lipodystrophy. AIDS 2001, 15:2049-2051.

81. Thoni GJ, Fedou C, Brun JF, Fabre J, Renard E, Reynes J, Varray A, Mercier J: Reduction of fat accumulation and lipid disorders by individualized light aerobic training in human immunodeficiency virus infected patients with lipodystrophy and/or dyslipidemia. Diabetes Metab 2002, 28:397-404.

\section{doi:10.1186/1742-6405-10-32}

Cite this article as: Paula et al:: Metabolic syndrome in HIV-infected individuals: underlying mechanisms and epidemiological aspects. AIDS Research and Therapy 2013 10:32.

\section{Submit your next manuscript to BioMed Central and take full advantage of:}

- Convenient online submission

- Thorough peer review

- No space constraints or color figure charges

- Immediate publication on acceptance

- Inclusion in PubMed, CAS, Scopus and Google Scholar

- Research which is freely available for redistribution 